\title{
IN VITRO STORAGE OF PAULOWNIA TOMENTOSA
}

\author{
A.A. El-Homosany ${ }^{*}$ and T.M. Noor El-Deen ${ }^{* *}$ \\ * In vitro Storage Plant and Cryopreservation Laboratory, National Gene Bank and Genetic \\ Resources, ARC, Giza, Egypt \\ ** Ornamental Plants and Landscape Gardening Res. Dept., Hort. Res. Inst., ARC, Giza, \\ Egypt
}

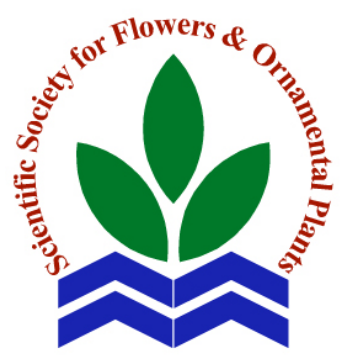

Scientific J. Flowers \& Ornamental Plants, 6(3):139-149(2019).

Received: 9/12/2019 Accepted: 26/12/2019

\begin{abstract}
Storage of plant species with high commercial potential as ornamental or for the alimentation and pharmacological has been used to preserve genetic variability and allowed the study of its properties in a controlled environment through the use of in vitro culture techniques. In this study, shoot tip explants of Paulownia tomentosa were excised from in vitro grown shootlets and cultured on Murashige and Skoog (MS) medium supplemented with $30 \mathrm{~g} \mathrm{l}^{-1}$ sucrose (control) and different concentrations of sucrose or sorbitol (20, 40, 50 and $\left.60 \mathrm{~g} \mathrm{l}^{-1}\right)$ and in combinations $(10+10,20+20,25+25$ and $30+30 \mathrm{~g} \mathrm{l}^{-1}$ ) and incubated under $18{ }^{\circ} \mathrm{C}$ in complete darkness for 2, 4, 6, 8 and 10 months. Results showed that all shoot tip explants conserved on MS medium augmented with different concentrations of sucrose or sorbitol and their combinations for 2 months, at the level of $30 \mathrm{~g} \mathrm{l}^{-1}$ sucrose (control) for 4 months recorded the best survival percentage (100\%). At the end of storage period (after 10 months), the highest survival percentage (83.33\%) was noticed when explants were conserved on MS medium with $30 \mathrm{~g} \mathrm{l}^{-1}$ (control) or $50 \mathrm{~g} \mathrm{l}^{-1}$ sucrose. Meanwhile, the lowest survival percentage (25.00\%) was achieved when explants were conserved on MS medium with $10 \mathrm{~g} \mathrm{l}^{-1}$ sucrose + $10 \mathrm{~g} \mathrm{l}^{-1}$ sorbitol. Moreover, it was observed an increasing of shoot length and number of proliferated shoots/explant during storage periods except all treatments with sorbitol and the treatment with sucrose plus sorbitol $\left(10+10 \mathrm{~g}^{-1}\right)$ remained without change in all storage periods.
\end{abstract}

Key words: in vitro storage, Paulownia tomentosa, slow growth, sorbitol, sucrose.

\section{INTRODUCTION}

Paulownia is a genus belonging to family Paulowniaceae (Scrophulariacae) indigenous to China and including nowadays over 20 species (Barton et al., 2007). Paulownia is very adaptable, widely distributed and extremely fast growing under optimum conditions. The timber is light yet strong, dries fast and has a beautiful grain, does not warp or crack and deform easily. The wood is easy to work with, and has excellent insulation properties. The trees can be used for reclamation of mined areas and especially for afforestation purposes, for making furniture, wooden details for planes and ships and other purposes useful for the industry (Zhu et al., 1986). The application of micropropagation techniques in agroforestry was essential because it offers a rapid way of producing genetically uniform cloned stock with high quality (Jagannathan and Micheal, 1986). Many authors reported the micropropagation of Paulownia sp. through bud formation from intermodal 
explants of P. kawakamii (Lobna, 2008) and P. elongata (Ipekci, 2003).

Paulownia species are rich in phenolic substances distributed in different parts and tissues of the tree (Smejkal et al., 2007; Si et al., 2013). It is one of the most useful medicinal plant species, tablets and injections derived from leaf, fruit and wood extracts are effective for bronchitis, especially relieving cough, reducing phlegm and blood pressure. Each of these parts contain one or more bioactive components, such as ursolic acid and matteucinol in the leaves (Ting et al., 2016).

Medicinal plants became the main constituents for medicines, food and other phyto-industries, these plants are endangered due to their extensive use in medicine, food and beverages industry. So, conservation of these natural resources is high priority. In vitro conservation of several ornamental species has applications based on the reduction of the metabolic activity on growth rate of in vitro cultures by modifying the culture medium and/or the culture conditions and prolong the duration between subcultures (depending on the species) without negatively affecting their regrowth (Engelmann, 2004; Lambardi and Ozudogru, 2013).

Using sucrose as osmotic agent was reported to reduce growth rate of the in vitro grown explants. Increase the level of sucrose in the media decrease the water content in the cell of plant and volume of cells, this decrease in cell volume would result in lower turgor pressure in the cells due to reduction of growth (Taiz and Zeiger, 2002). In this respect, $0.2 \mathrm{M}$ sucrose was highly recommended for in vitro conservation of many plant species due to its ability to reduce growth and to maintain recovery after storage at full capacity (Rabba'a et al., 2012; Sharaf et al., 2012; Tahtamouni et al., 2001; Younis, 2012).

Sorbitol is a sugar alcohol was used on shoots conservation of Saintpaulia ionantha to decrease the shoot height irrespective of its concentration (Moges et al., 2004). Sorbitol has also reduced growth in Amygdalus communis and extended the subculture intervals to up to 4 months (Shibli et al., 1999). Sorbitol at $0.1 \mathrm{M}$ concentration was found to be effective in decreasing growth in Teucrium polium L. and Acheillea frarantissima respectively as reported by Rabba'a et al. (2012) and Younis (2012).

The use of low temperature from 4 to $18^{\circ} \mathrm{C}$ and nutrient medium supplementation osmo-regulators with sucrose have been used to conserve explants for clonal propagation such as tubers, roots and ornamental species (Ozudogru et al., 2010). The low temperature increases the transfer interval to new medium and often regardless of the type and concentration of carbohydrate used (Lima-Brito et al., 2011).

The main goal of this study was to evaluate the best survival and recovery of paulownia shoot tips after storage on MS medium containing different sucrose and sorbitol concentrations at low temperature.

\section{MATERIALS AND METHODS}

This study was carried out in the in vitro Storage Plant and Cryopreservation Laboratory at National Gene Bank, Agricultural Research Center, Giza, Egypt from 2018 to 2019 years.

\section{In vitro propagation: \\ Plant collection and surface sterilization:}

Stem nodes of 10-15 cm long were taken from adult selected trees in the greenhouse at National Gene Bank at the beginning of April, 2018. After removing the leaves, shoots were put under running tap water for about one hour, then sterilized under laminar flow hood condition. Sodium hypochlorite solution was prepared using commercial bleach "Clorox" (5.25\% available chlorine) at $10 \%$ concentration. The shoots were dipped for 10 minutes in such solution before rinsing three times in sterile distilled water, 5 minutes for each rinsing. 


\section{Culture media and growth conditions:}

After the sterilization, stem nodes were cultured in establishment culture media. The $\mathrm{pH}$ of different media was adjusted to 5.7 before autoclaving at $100 \mathrm{~K}$. pa (1.5 P.S.I) and $121^{\circ} \mathrm{C}$ for 20 minutes, then left to cool for 24 hours before being used. The cultures of different experiments were incubated at temperatures almost maintained between $25 \pm 2{ }^{\circ} \mathrm{C}$ and photoperiods of 16 hours day and 8 hours night supplied by fluorescent lamp to provide light intensity of 3000 lux.

For establishment stage, stem node explants was separately cultured in $250 \mathrm{~mm}$ jars filled with $25 \mathrm{ml}$ of full strength Murashige and Skoog (1962) (MS) or Lloyd and McCown (1980) (WPM) medium plus $3 \%$ sucrose, $0.7 \%$ agar and supplemented with Benzyl Adenine (BA) at 0.0 (control), 0.2 or $0.5 \mathrm{mg}^{-1}$ in combination with Naphthalene Acetic Acid (NAA) at 0.0 or $0.05 \mathrm{mg} 1^{-1}$. Survival percentages, and shoot length $(\mathrm{cm})$ were determined after four weeks.

For proliferation stage, approximately uniform growing shoots $1.5 \mathrm{~cm}$ in length were aseptically transferred after four weeks to proliferation medium according to Ely et al. (2013) which was consisted of MS salts and vitamins supplemented with BA at 2.0 $\mathrm{mg}^{-1}$ in combination with NAA at 0.05 $\mathrm{mg} \mathrm{l}^{-1}$. The shoots were cultured into 250 $\mathrm{mm}$ glass jars filled with $25 \mathrm{ml}$ of medium. The proliferated shoots were subcultured onto fresh medium each of 4 weeks period. For rooting stage, uniform proliferated shoots about $2 \mathrm{~cm}$ in length from the $3^{\text {rd }}$ subculture were transferred to $250 \mathrm{~mm}$ glass jars filled with $25 \mathrm{ml}$ of rooting medium which consisted of MS medium with vitamins according to Nada and Taoufik (2013) plus 3\% sucrose, $0.7 \%$ agar and supplemented with IBA $0.5 \mathrm{mg} \mathrm{l}^{-1}$. Rooted shoots were rinsed with tap water to remove the medium from the roots and put it in a Rizolex fungicide $\left(1.0 \mathrm{~g} \mathrm{l}^{-1}\right)$ for 2 min before transplanting into a mixture of peat moss : sand ( $1: 1$ by volume) for 6 weeks in growth chamber $\left(22^{\circ} \mathrm{C} \pm 1\right)$ before being transferred to the greenhouse with artificial lighting and $80 \%$ relative humidity.

\section{In vitro storage: \\ Storage conditions:}

Shoot tip explants of paulownia $(1 \mathrm{~cm}$ long and 2-3 leaves) were taken from in vitro cultures after the $3^{\text {rd }}$ subculture and separately cultured in $150 \mathrm{~mm}$ jars filled with $25 \mathrm{ml}$ of full-strength MS medium plus $0.7 \%$ agar and different concentrations of sucrose or sorbitol alone and in a combination as follows:

1. Sucrose at $30 \mathrm{~g} \mathrm{l}^{-1}$ (control).

2. Sucrose at $20 \mathrm{~g} \mathrm{l}^{-1}$.

3. Sucrose at $40 \mathrm{~g} \mathrm{l}^{-1}$.

4. Sucrose at $50 \mathrm{~g}^{-1}$.

5. Sucrose at $60 \mathrm{~g}^{-1}$.

6. Sorbitol at $20 \mathrm{~g} \mathrm{l}^{-1}$.

7. Sorbitol at $40 \mathrm{~g} \mathrm{l}^{-1}$.

8. Sorbitol at $50 \mathrm{~g} \mathrm{l}^{-1}$.

9. Sorbitol at $60 \mathrm{~g} \mathrm{l}^{-1}$.

10. Sucrose at $10 \mathrm{~g} \mathrm{l}^{-1}+$ sorbitol at $10 \mathrm{~g} \mathrm{l}^{-1}$.

11. Sucrose at $20 \mathrm{~g} \mathrm{l}^{-1}+$ sorbitol at $20 \mathrm{~g} \mathrm{l}^{-1}$.

12. Sucrose at $25 \mathrm{~g} \mathrm{l}^{-1}+$ sorbitol at $25 \mathrm{~g} \mathrm{l}^{-1}$.

13. Sucrose at $30 \mathrm{~g} \mathrm{l}^{-1}+$ sorbitol at $30 \mathrm{~g} \mathrm{l}^{-1}$.

All cultures were stored at $18{ }^{\circ} \mathrm{C}$ in a complete darkness. Survival percentage of shoot tip explants of each treatment was recorded at the end of each storage period (five storage periods 2 months for each one).

The survived shoot tip explants of paulownia cultures were taken at the end of storage period and cultured in $250 \mathrm{~mm}$ jars filled with $25 \mathrm{ml}$ of full-strength MS medium plus $3 \%$ sucrose, $0.7 \%$ agar, BA at $2.0 \mathrm{mg} \mathrm{l}^{-1}$ and NAA at $0.05 \mathrm{mg}^{-1}$. The cultures were incubated at $25 \pm 2{ }^{\circ} \mathrm{C}$ and photoperiods of 16 hours day and 8 hours night supplied by fluorescent lamp to provide light intensity of 3000 lux.

All experiments were arranged as factorial experiment in a completely randomized design. The obtained data were statistically analyzed according to Snedecor and Cochran (1982). Duncan's Multiple Range Test as described by Duncan (1955) was employed to estimate the significant of differences among the treatment means. 
RESULTS AND DISCUSSION

\section{In vitro propagation:}

Data in Table (1) and Fig. (1) revealed that the highest survival percentage for paulownia explants was noticed with MS medium (77.78 \%) compared to WPM medium (66.66\%) without significant difference between them. Specific effect of growth regulator revealed that $\mathrm{BA}$ at 0.5 $\mathrm{mg} \mathrm{l}^{-1}$ plus $0.05 \mathrm{mg} \mathrm{l}^{-1}$ NAA exhibited the highest survival percentage (83.33\%). Insignificant differences between tested BA at 0.2 and $0.5 \mathrm{mg} \mathrm{l}^{-1}$ on survival percentage (75.00 and 83.33\%, respectively) were existed. Meanwhile, control (0.0 BA+ 0.0 NAA) gave the lowest survival percentage (58.33\%). The interactions between the two studied factors showed that MS medium supplemented with BA at $0.5 \mathrm{mg} \mathrm{l}^{-1}$ plus NAA at $0.05 \mathrm{mg} \mathrm{l}^{-1}$ recorded the highest significant survival (91.67\%). Meanwhile, the control (WPM or MS) without growth regulators gave the lowest survival percentage (58.33\%) for both media.

As for the average shoot length, there was insignificant difference between the studied media. The highest shoot length $(1.22 \mathrm{~cm})$ was obtained by MS medium compared with WPM medium $(0.97 \mathrm{~cm})$ without significant differences between them. Specific effect of growth regulator revealed that BA at $0.5 \mathrm{mg} \mathrm{l}^{-1}$ plus $0.05 \mathrm{mg} \mathrm{l}^{-1}$ NAA exhibited the highest insignificant mean shoot length $(1.36 \mathrm{~cm})$ compared with
$0.2 \mathrm{mg} \mathrm{l}^{-1}$ plus $0.05 \mathrm{mg} \mathrm{l}^{-1}$ NAA $(1.10 \mathrm{~cm})$. On the other hand, both media without BA or NAA recorded the lowest shoot length $(0.82 \mathrm{~cm})$. The interactions showed that MS medium supplemented with BA at $0.5 \mathrm{mg} \mathrm{l}^{-1}$ plus NAA at $0.05 \mathrm{mg} \mathrm{l}^{-1}$ recorded the highest significant shoot length $(1.55 \mathrm{~cm})$, followed by MS medium supplemented with BA at 0.2 $\mathrm{mg} \mathrm{l}^{-1}$ plus NAA at $0.05 \mathrm{mg} \mathrm{l}^{-1}(1.25 \mathrm{~cm})$ without significant differences with WPM medium supplemented with BA at $0.5 \mathrm{mg} \mathrm{l}^{-1}$ plus NAA at $0.05 \mathrm{mg} \mathrm{l}^{-1}(1.17 \mathrm{~cm})$. While, WPM medium or MS medium without BA and IBA (control) gave the lowest insignificant shoot length $(0.77$ and $0.78 \mathrm{~cm}$, respectively).

The presented data during the establishment stage of paulownia showed that the highest survival percentages and shoot length were obtained with MS medium contained BA at 0.5 plus NAA at $0.05 \mathrm{mg} \mathrm{l}^{-1}$ (Table 1). The current results are in agreement with Atanas and Svetla (2014) who studied the micropropagation of three different genotypes of paulownia ( $P$. elongata; P. tomentosa x $P$. fortunei hybrid and ( $P$. elongata $\times$. tomentosa) $\times$. $P$. elongate complex hybrid) on basal media MS, DKW, QL, McC and N6 plus BAP at $0.5 \mathrm{mg} \mathrm{l}^{-1}$ and IBA at $0.01 \mathrm{mg} \mathrm{l}^{-1}$ for multiplication efficiency. They found that MS basal salt composition induced higher multiplication coefficient in $P$. tomentosa $\mathrm{x}$ $P$. fortunei hybrid $(3,9)$, ( $P$. elongata $\times P$. tomentosa) x P. elongata complex hybrid (2)

Table 1. Effect of medium type and growth regulators (BA and NAA) levels on survival percentage and shoot length of Paulownia tomentosa during establishment stage.

\begin{tabular}{lccc}
\hline \multicolumn{1}{c}{ Treatments $\left(\mathbf{m g ~ l}^{-\mathbf{1}}\right)$} & WPM & $\begin{array}{c}\text { Medium types } \\
\text { MS }\end{array}$ & Mean \\
\hline 0.0 BA + 0.0 NAA & \multicolumn{3}{c}{ Survival\% } \\
0.2 BA + 0.05 NAA & $58.33 \mathrm{c}$ & $58.33 \mathrm{c}$ & $58.33 \mathrm{~B}$ \\
0.5 BA + 0.05 NAA & $66.66 \mathrm{bc}$ & $83.33 \mathrm{ab}$ & $75.00 \mathrm{AB}$ \\
Mean & $75.00 \mathrm{a}-\mathrm{c}$ & $91.67 \mathrm{a}$ & $83.33 \mathrm{~A}$ \\
\hline & $66.66 \mathrm{~A}$ & $77.78 \mathrm{~A}$ & \\
0.0 BA + 0.0 NAA & & Shoot length (cm) \\
0.2 BA + 0.05 NAA & $0.77 \mathrm{~d}$ & $0.87 \mathrm{~d}$ & $0.82 \mathrm{~B}$ \\
0.5 BA + 0.05 NAA & $0.95 \mathrm{~cd}$ & $1.25 \mathrm{~b}$ & $1.10 \mathrm{AB}$ \\
Mean & $1.17 \mathrm{bc}$ & $1.55 \mathrm{a}$ & $1.36 \mathrm{~A}$ \\
\hline
\end{tabular}

Means followed by the same letter (s) are not significantly different from each other at $5 \%$ level. 


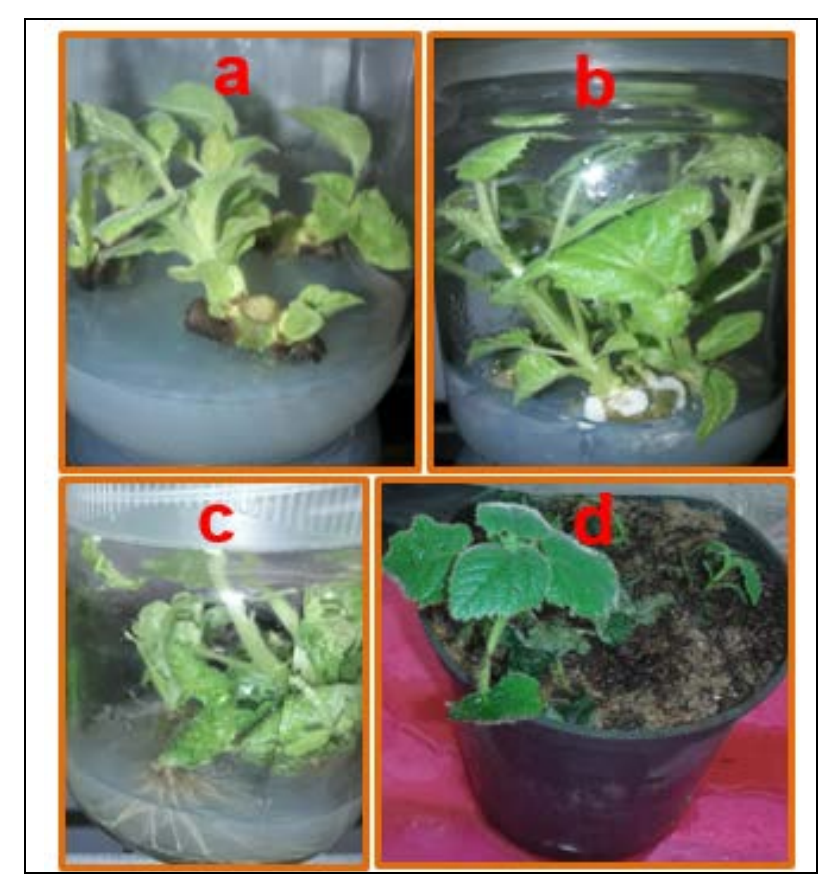

Fig. 1. Micropropagation of Paulownia tomentosa. (a) Starting stage on MS medium containing $0.5 \mathrm{mg}^{-1} \mathrm{BAP}$ and 0.05 mg $1^{-1}$ NAA, (b) Multiplication stage on MS medium $+2.0 \mathrm{mg}^{-1} \mathrm{BA}+0.05 \mathrm{mg} \mathrm{1}^{-1} \mathrm{NAA}$, (c) Rooting stage on MS medium + 0.5 mg1 $^{-}$ ${ }^{1}$ IBA and (d) Acclimatization stage on medium containing Peatmoss : Sand (1:1).

and P. elongata (1,8). Also, Ely et al. (2013) found that explants established on MS medium with $0.2 \mathrm{mg} \mathrm{l}^{-1} \mathrm{BAP}, 0.2 \mathrm{mg} \mathrm{l}^{-1} \mathrm{GA}$ and $0.05 \mathrm{mg} \mathrm{l}^{-1} \mathrm{NAA}$; the shoot tips developed rapidly and each nodal axils produces single vegetative buds after 10-12 days. Meanwhile, Lila et al. (2016) reported that nodal explants of Paulownia tomentosa cultured on MS medium supplemented with $1.0 \mathrm{mg} \mathrm{l}^{-1}$ BAP and $0.1 \mathrm{mg} \mathrm{l}^{-1}$ NAA recorded the best initiation medium for number of leaves/explant (8-12), shoot length (2.5-3.5 $\mathrm{cm}$ ) and number of nodes/shoot (3-4).

\section{In vitro storage:}

Data in Table (2) clear the effect of different sucrose and sorbitol concentrations on survival percentage of paulownia shoot tip explants stored at $18{ }^{\circ} \mathrm{C}$ under complete darkness. Results about storage period revealed that all explants conserved for 2 months were able to survival $(100 \%)$, this percentage decreased to $83.33 \%$ for 4 months without significant differences between them. Also, the survival percentage decreased without significant differences between the storage periods of 6 to 8 months (78.2\% and $67.33 \%$ respectively). While, the lowest survival percentage of shoot tip explants were noticed after storage for 10 months (55.77\%).

Regarding the effect of different sucrose and sorbitol concentrations results cleared that the medium with $30 \mathrm{~g}^{-1}$ (control) showed the highest survival percentage (93.33\%) followed without significant differences among them by survival percentage of explants stored on medium with 50 and $40 \mathrm{~g}^{-1}$ sucrose $(90.00 \%$ and 88.33\%), explants stored on medium with 20 g $1^{-1}$ sucrose (81.66\%), explants storage on medium with $20 \mathrm{~g}^{-1}$ sucrose $+20 \mathrm{~g}^{-1}$ sorbitol, $25 \mathrm{~g}^{-1}$ sucrose $+25 \mathrm{~g} 1^{-1}$ sorbitol and $30 \mathrm{~g}^{-1}$ sucrose $+30 \mathrm{~g}^{-1}$ sorbitol (81.66\%, 81.66\% and 81.66\%). Meanwhile, explants stored on medium with $10 \mathrm{~g} \mathrm{1^{-1 }}$ sucrose $+10 \mathrm{~g}^{-1}$ sorbitol showed the lowest survival percentage (58.33\%).

Concerning the effect of interaction between different storage periods and different sucrose and sorbitol concentrations results revealed that all explants stored on 30 g $1^{-1}$ sucrose (control) or media with 20,40 , 50 and $60 \mathrm{~g}^{-1}$ sucrose or sorbitol, media with $10 \mathrm{~g}^{-1}$ sucrose $+10 \mathrm{~g} 1^{-1}$ sorbitol, $20 \mathrm{~g}^{-1}$ sucrose $+20 \mathrm{~g} 1^{-1}$ sorbitol, $25 \mathrm{~g} 1^{-1}$ sucrose + $25 \mathrm{~g} 1^{-1}$ sorbitol and $30 \mathrm{~g} 1^{-1}$ sucrose $+30 \mathrm{~g} 1^{-1}$ sorbitol for 2 months and all explants stored on $30 \mathrm{~g} 1^{-1}$ sucrose (control) for 4 months were able to still alive as the survival percentage was $100 \%$. This percentage was reduced with significant differences to $91.66 \%$ when explants stored on medium with 40,50 and $60 \mathrm{~g}^{-1}$ sucrose for 4 months, explants stored on medium with 30 g $1^{-1}$ sucrose (control), 40 or $50 \mathrm{~g}^{-1}$ sucrose for 6 months, explants stored on medium with $30 \mathrm{~g}^{-1}$ sucrose (control) for 8 months. The same survival percentage $83.33 \%$ was achieved when explants stored on medium with $20 \mathrm{~g} 1^{-1}$ sucrose, $40 \mathrm{~g} 1^{-1}$ sorbitol, $20 \mathrm{~g} 1^{-1}$ sucrose $+20 \mathrm{~g}^{-1}$ sorbitol, $25 \mathrm{~g}^{-1}$ sucrose + 
Table 2. Effect of sugar types, concentrations and storage periods on survival percentage of Paulownia tomentosa shoot tip explants stored at $18{ }^{\circ} \mathrm{C}$ under complete darkness.

\begin{tabular}{lcccccc}
\hline \multirow{2}{*}{ Full MS plus treatments $\left(\mathbf{g ~}^{-\mathbf{1}}\right)$} & $\mathbf{2}$ & $\mathbf{4}$ & $\mathbf{6}$ & $\mathbf{8}$ & $\mathbf{1 0}$ & Mean \\
\hline $\mathbf{3 0}$ sucrose (control) & $100.00 \mathrm{a}$ & $100.00 \mathrm{a}$ & $91.66 \mathrm{~b}$ & $91.66 \mathrm{~b}$ & $83.33 \mathrm{c}$ & $93.33 \mathrm{~A}$ \\
$\mathbf{2 0}$ sucrose & $100.00 \mathrm{a}$ & $83.33 \mathrm{c}$ & $83.33 \mathrm{c}$ & $75.00 \mathrm{~d}$ & $66.66 \mathrm{e}$ & $81.66 \mathrm{~A}-\mathrm{C}$ \\
$\mathbf{4 0}$ sucrose & $100.00 \mathrm{a}$ & $91.66 \mathrm{~b}$ & $91.66 \mathrm{~b}$ & $83.33 \mathrm{c}$ & $75.00 \mathrm{~d}$ & $88.33 \mathrm{AB}$ \\
$\mathbf{5 0}$ sucrose & $100.00 \mathrm{a}$ & $91.66 \mathrm{~b}$ & $91.66 \mathrm{~b}$ & $83.33 \mathrm{c}$ & $83.33 \mathrm{c}$ & $90.00 \mathrm{AB}$ \\
$\mathbf{6 0}$ sucrose & $100.00 \mathrm{a}$ & $91.66 \mathrm{~b}$ & $75.00 \mathrm{~d}$ & $66.66 \mathrm{e}$ & $50.00 \mathrm{~g}$ & $76.66 \mathrm{~B}-\mathrm{D}$ \\
$\mathbf{2 0}$ sorbitol & $100.00 \mathrm{a}$ & $75.00 \mathrm{~d}$ & $66.66 \mathrm{e}$ & $50.00 \mathrm{~g}$ & $33.33 \mathrm{i}$ & $65.00 \mathrm{DE}$ \\
$\mathbf{4 0}$ sorbitol & $100.00 \mathrm{a}$ & $83.33 \mathrm{c}$ & $75.00 \mathrm{~d}$ & $50.00 \mathrm{~g}$ & $33.33 \mathrm{i}$ & $68.33 \mathrm{C}-\mathrm{E}$ \\
$\mathbf{5 0}$ sorbitol & $100.00 \mathrm{a}$ & $75.00 \mathrm{~d}$ & $66.66 \mathrm{e}$ & $58.33 \mathrm{f}$ & $41.66 \mathrm{~h}$ & $68.33 \mathrm{C}-\mathrm{E}$ \\
$\mathbf{6 0}$ sorbitol & $100.00 \mathrm{a}$ & $75.00 \mathrm{~d}$ & $66.66 \mathrm{e}$ & $50.00 \mathrm{~g}$ & $33.33 \mathrm{i}$ & $65.00 \mathrm{DE}$ \\
$\mathbf{1 0}$ sucrose $+\mathbf{1 0}$ sorbitol & $100.00 \mathrm{a}$ & $66.66 \mathrm{e}$ & $58.33 \mathrm{f}$ & $41.66 \mathrm{~h}$ & $25.00 \mathrm{j}$ & $58.33 \mathrm{E}$ \\
$\mathbf{2 0}$ sucrose $+\mathbf{2 0}$ sorbitol & $100.00 \mathrm{a}$ & $83.33 \mathrm{c}$ & $83.33 \mathrm{c}$ & $75.00 \mathrm{~d}$ & $66.66 \mathrm{e}$ & $81.66 \mathrm{~A}-\mathrm{C}$ \\
$\mathbf{2 5}$ sucrose $+\mathbf{2 5}$ sorbitol & $100.00 \mathrm{a}$ & $83.33 \mathrm{c}$ & $83.33 \mathrm{c}$ & $75.00 \mathrm{~d}$ & $66.66 \mathrm{e}$ & $81.66 \mathrm{~A}-\mathrm{C}$ \\
$\mathbf{3 0}$ sucrose $+\mathbf{3 0}$ sorbitol & $100.00 \mathrm{a}$ & $83.33 \mathrm{c}$ & $83.33 \mathrm{c}$ & $75.00 \mathrm{~d}$ & $66.66 \mathrm{e}$ & $81.66 \mathrm{~A}-\mathrm{C}$ \\
$\mathbf{M e a n}$ & $100.00 \mathrm{~A}$ & $83.33 \mathrm{AB}$ & $78.20 \mathrm{~B}$ & $67.33 \mathrm{BC}$ & $55.77 \mathrm{C}$ & \\
\hline
\end{tabular}

Means followed by the same letter (s) are not significantly different from each other at $5 \%$ level.

$25 \mathrm{~g} 1^{-1}$ sorbitol and $30 \mathrm{~g} 1^{-1}$ sucrose $+30 \mathrm{~g} 1^{-1}$ sorbitol for 4 months, on medium with $20 \mathrm{~g} 1^{-1}$ sucrose, $20 \mathrm{~g} 1^{-1}$ sucrose $+20 \mathrm{~g} 1^{-1}$ sorbitol, 25 g $1^{-1}$ sucrose $+25 \mathrm{~g}^{-1}$ sorbitol and $30 \mathrm{~g}^{-1}$ sucrose $+30 \mathrm{~g}^{-1}$ sorbitol for 6 months, explants stored on medium with 40 and $50 \mathrm{~g}^{-1}$ sucrose for 8 months, explants stored on medium with $30 \mathrm{~g}^{-1}$ sucrose and $50 \mathrm{~g} 1^{-1}$ sucrose for 10 months. On the other hand, the lowest survival percentage $25.00 \%$ was noticed when explants were stored on medium with $10 \mathrm{~g}^{-1}$ sucrose $+10 \mathrm{~g}^{-1}$ sorbitol for 10 months. The survival percentage of shoot tip explants stored on different period and other media with sucrose and sorbitol concentrations in this investigation came in-between.

The obtained results are in agreement with Tyagi et al. (2009) who revealed that storage of Elettaria cardamomum cultures was about $70 \%$ of survival and $96 \%$ regrowth when storage at $25{ }^{\circ} \mathrm{C}$ up to 18 months on half strength MS, fortified with 30 $\mathrm{g} \mathrm{l}^{-1}$ sucrose. Also, Gopal et al. (2002) reported that preserved micro-plants of six genotypes of Solanum tuberosum was achieved on MS medium supplemented with
$20 \mathrm{~g} \mathrm{l}^{-1}$ sucrose along with $40 \mathrm{~g} \mathrm{l}^{-1}$ sorbitol at $24{ }^{\circ} \mathrm{C}$ for 12 months without any phenotypic abnormalities at a photoperiod of 16/8 h with survival percentage (77.8\%). Similarly, Watt et al. (2009) stored successfully the shoots of Saccharum sp. on half strength MS medium with $30 \mathrm{~g} \mathrm{l}^{-1}$ sorbitol at 18 and $24{ }^{\circ} \mathrm{C}$ for 8 months, the highest survival percentage and shoot regrowth (90\%) were observed in cultures stored at $18{ }^{\circ} \mathrm{C}$. However, microshoots of Podophyllum peltatum cultured on MS medium plus 2\% mannitol or sorbitol at 10 and $25{ }^{\circ} \mathrm{C}$ recorded $100 \%$ survival percentage (Lata et al., 2010).

In this respect Moges et al. (2004); Shibli et al. (2005) and Tahtamouni et al. (2001) reported that adding sorbitol on elevated levels led to a high death percentage in many plants by accumulation of carbohydrates in the cells reached to toxic levels. This explains the decrease of survival percentage (41.66 and 33.33\%) of shoot tip explants at the end of storage periods (10 months) when stored on MS medium with different sorbitol concentrations.

All cultures of paulownia shoot tip after storage were propagated successfully on full 
strength MS medium plus 3\% sucrose, $0.7 \%$ agar, BA at $2.0 \mathrm{mg} \mathrm{l}^{-1}$ and NAA at $0.05 \mathrm{mg}^{-1}$ (Fig. 2).

During the present investigation, we noticed that shoot tip explants for all treatments in the first storage period (after 2 months of storage) were remained unchanged. While, during the second and third storage periods (after 4 and 6 months of storage) we observed an elongation of shoot length on the explant from 0.5 to $1.0 \mathrm{~cm}$ for all treatments of sucrose (30 (control), 20, 40, 50 and $60 \mathrm{~g}^{-1}$ ) and treatments of sucrose plus sorbitol $(20+20,25+25$ and $\left.30+30 \mathrm{~g}^{-1}\right)$. Also, an increase in number of proliferated shoots/explant on the explants cultured on MS medium with $30 \mathrm{~g} 1^{-1}$ sucrose (3 shoots/explant), (2 shoots/explant) on treatments with $20,40,50$ and $60 \mathrm{~g}^{-1}$ sucrose, one shoot/explant on treatments with sucrose plus sorbitol $(20+20,25+25$ and $30+30 \mathrm{~g}^{-1}$ ). Meanwhile, shoot tip explants for all treatments of sorbitol (20, 40, 50 and $60 \mathrm{~g}^{-1}$ ) and treatment with sucrose

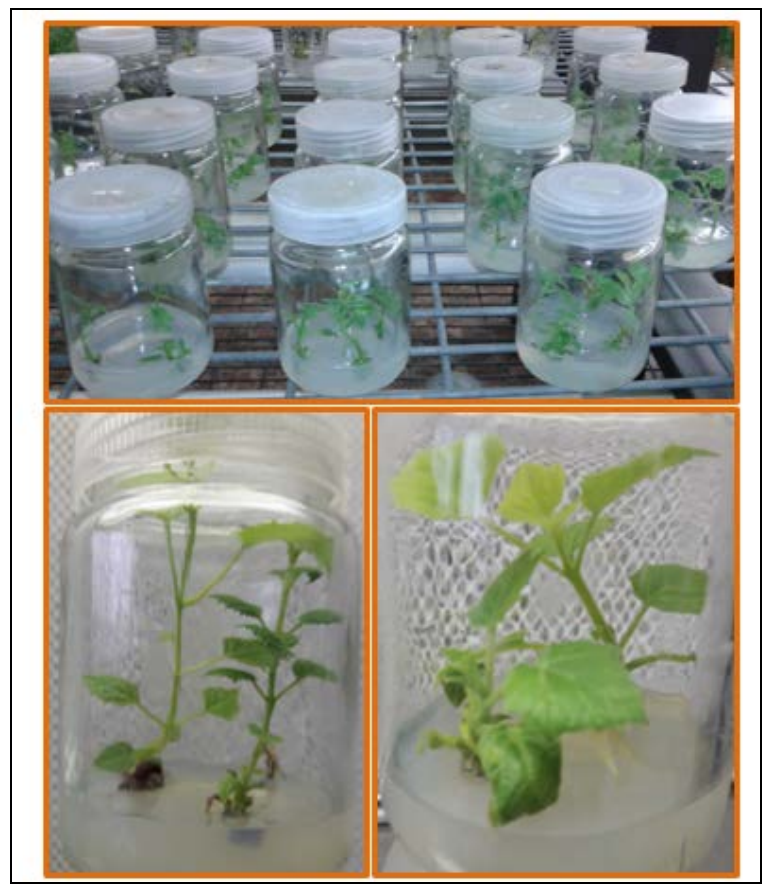

Fig. 2. Proliferation shoot tip explants of Paulownia tomentosa cultured on multiplication medium $\mathrm{MS}+\mathbf{2 . 0}$ $\mathrm{g} \mathrm{l}^{-1} \mathrm{BA}+0.05 \mathrm{~g} \mathrm{l}^{-1} \mathrm{NAA}$ after 10 months of storage on different media. plus sorbitol $\left(10+10 \mathrm{~g}^{-1}\right)$ were remained unchanged either on shoot length or number of proliferated shoots/explant (Table 3 and Fig. 3).

Results of the shoot tip explants stored for fourth period (after 8 months) revealed that an elongation of shoot length on the explant from 1.0 to $2.0 \mathrm{~cm}$ for all treatments of sucrose (30 (control), 20, 40, 50 and 60 g $1^{-1}$ ), elongation of shoot length on the explant from 0.5 to $1.0 \mathrm{~cm}$ for treatments of sucrose plus sorbitol $(20+20,25+25$ and $\left.30+30 \mathrm{~g}^{-1}\right)$. Also, an increase in number of proliferated shoots/explant on the explants cultured on MS medium with 30 (control), 20, 40, 50 and $60 \mathrm{~g}^{-1}$ sucrose (3 shoots/explant), one shoot/explant on treatments with sucrose plus sorbitol $(20+$ $20,25+25$ and $30+30 \mathrm{~g}^{-1}$ ). Meanwhile, shoot tip explants for all treatments of sorbitol (20, 40, 50 and $60 \mathrm{~g} 1^{-1}$ ) and treatment with sucrose plus sorbitol $(10+$ $10 \mathrm{~g}^{-1}$ ) were remained unchanged either on shoot length or number of proliferated shoots/explant (Table 3 and Fig. 3).

For fifth period (after 10 months) we recorded that an elongation of shoot length on the explant from 2.0 to $3.0 \mathrm{~cm}$ for all treatments of sucrose (30 (control), 20, 40, 50 and $60 \mathrm{~g}^{-1}$ ) and elongation of shoots on the explant from 0.5 to $1.0 \mathrm{~cm}$ with treatments of sucrose plus sorbitol $(20+20$, $25+25$ and $30+30$ g $\left.1^{-1}\right)$. Moreover, an increase in number of proliferated shoots/explant on the explants cultured on MS medium with 30 (control), 20, 40, 50 and $60 \mathrm{~g}^{-1}$ sucrose (3 shoots/explant), (2 shoots/explant) on treatments with sucrose plus sorbitol $(20+20,25+25$ and $30+$ $30 \mathrm{~g}^{-1}$ ). Meanwhile, shoot tip explants for all treatments of sorbitol (20, 40, 50 and 60 g $1^{-1}$ ) and treatment with sucrose plus sorbitol $\left(10+10 \mathrm{~g}^{-1}\right)$ were remained unchanged either on shoot length or number of proliferated shoots/explant (Table 3 and Fig. 3). 
Table 3. Development of Paulownia tomentosa shoot tip explants during storage for 10 months at $18{ }^{\circ} \mathrm{C}$ under complete darkness.

\begin{tabular}{|c|c|c|c|c|c|c|c|c|c|c|}
\hline \multirow{3}{*}{$\begin{array}{l}\text { Full MS plus treatments } \\
\qquad\left(\mathrm{g} \mathrm{l}^{-1}\right)\end{array}$} & \multicolumn{10}{|c|}{ Period (month) } \\
\hline & \multicolumn{2}{|c|}{2} & \multicolumn{2}{|c|}{4} & \multicolumn{2}{|c|}{6} & \multicolumn{2}{|c|}{8} & \multicolumn{2}{|c|}{10} \\
\hline & SL & NS & SL & NS & SL & NS & SL & NS & SL & NS \\
\hline 30 sucrose (control) & - & - & + & +++ & + & +++ & ++ & +++ & +++ & +++ \\
\hline 20 sucrose & - & - & + & ++ & + & ++ & ++ & +++ & +++ & +++ \\
\hline 40 sucrose & - & - & + & ++ & + & ++ & ++ & +++ & +++ & +++ \\
\hline 50 sucrose & - & - & + & ++ & + & ++ & ++ & +++ & +++ & +++ \\
\hline 60 sucrose & - & - & + & ++ & + & ++ & ++ & +++ & +++ & +++ \\
\hline 20 sorbitol & - & - & - & - & - & - & - & - & - & - \\
\hline 40 sorbitol & - & - & - & - & - & - & - & - & - & - \\
\hline 50 sorbitol & - & - & - & - & - & - & - & - & - & - \\
\hline 60 sorbitol & - & - & - & - & - & - & - & - & - & - \\
\hline 10 sucrose +10 sorbitol & - & - & - & - & - & - & - & - & - & - \\
\hline 20 sucrose +20 sorbitol & - & - & + & + & + & + & + & + & + & ++ \\
\hline 25 sucrose +25 sorbitol & - & - & + & + & + & + & + & + & + & ++ \\
\hline 30 sucrose +30 sorbitol & - & - & + & + & + & + & + & + & + & ++ \\
\hline
\end{tabular}

SL = shoot length, $(-)=$ no elongation of shoot length, $(+,++,+++)=($ elongated shoot length with $0.5-1$, $1-2,2-3 \mathrm{~cm}), \mathrm{SN}=$ shoot number, $(-)=$ no profilated shoots $/$ explant, $(+,++,+++)=($ number of profilated shoots/explant with $1,2,3)$.

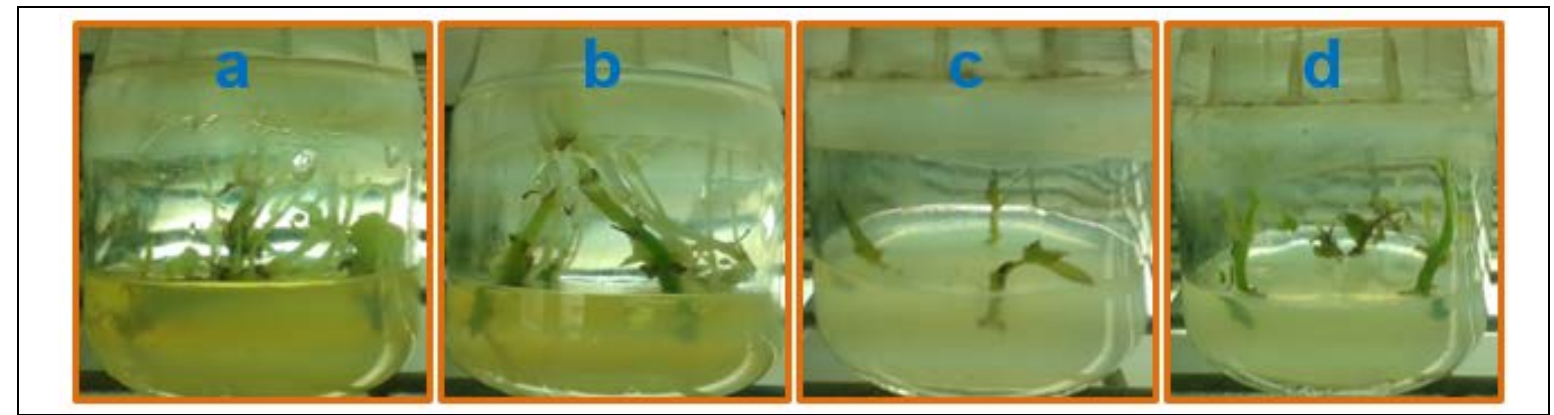

Fig. 3. Shoot tip explants of Paulownia tomentosa after 10 months of storage on MS medium containing (a) $30 \mathrm{~g} \mathrm{l}^{-1}$ sucrose (control), (b) $40 \mathrm{~g} \mathrm{l}^{-1}$ sucrose, (c) $40 \mathrm{~g} \mathrm{l}^{-1}$ sorbitol and (d) $20 \mathrm{~g} \mathrm{l}^{-1}$ sucrose $+20 \mathrm{~g} \mathrm{l}^{-1}$ sorbitol.

It was observed that increases of shoot length and number of proliferated shoots/explant occurred when the storage periods was increased with all treatments in this investigation except all treatments with sorbitol and the treatment with sucrose plus sorbitol $\left(10+10 \mathrm{~g}^{-1}\right)$ remained without change in all storage periods.

\section{CONCLUSION}

This study for storage under minimal growth media by osmotic agents is the first trend of paulownia. Based on the results of this study, it can be concluded that sorbitol fortified to MS medium can slow the explants growth and recommended to storage of Paulownia tomentosa. Also, results presented from our study could be useful for the establishment of an in vitro protocol for the storage of paulownia which allow to be applied to other species.

\section{REFERENCES}

Atanas, C. and Svetla, Y. (2014). Microprop agation of paulownia species and hybrids. First National conference of biotechnology, Sofia Univ., Bulgaria, 100(4):223-230. 
Barton, I.I.; Nicholas, I.D. and Ecroyd, C.E. (2007). Paulownia. Forest Research Bulletin No. 231, 49 p.

Duncan, D.B. (1955). Multiple range and multiple $\mathrm{F}$ test. Journal of Biometrics, 11:1-42.

Ely, Z.; Maria, P.; Roumiana, V.I.; Daniela, S. and Boris, K. (2013). A tissue culture technique for propagation of Paulownia elongata tree. Biological Diversity and Conservation, 6(3):1-5.

Engelmann, F.(2004). Plant cryopreservation: progress and prospects. In Vitro Cellular \& Developmental Biology Plant, 40:427433.

Gopal, J.; Chamail, A. and Sarkar, D. (2002). Slow growth in vitro conservation of potato germplasm at normal propagation temperature. Potato Res., 45:203-213.

Ipekci, Z.G.N. (2003). Direct somatic embryogenesis and synthetic seed production from Paulownia elongata. Plant Cell Rep., 22:16-24.

Jagannathan, L. and Micheal, M. (1986). Phenotypic and ploidy status of Paulownia tomentosa trees regenerated from culture hypocotyls. Plant cell, Tissue and organ culture, 7:227-236.

Lambardi, M. and Ozudogru, E.A. (2013). Advances in the safe storage of micropropagated woody plants at low temperature. Acta Hortic. 988:29-42.

Lata, H.; Moraes, R.M.; Bertoni, B. and Pereira, A.M.S. (2010). In vitro germplasm conservation of Podophyllum peltatum L. under slow growth conditions. In Vitro Cell Dev. Biol. Plant, 46:22-27.

Lila, B.M.; Nisha, S.; Saraswoti, K.; Jay, R.J.; Jibaraj, A.; Gaurav, C.G.; Bishnu, P.M.; Sabari, R. and Niranjan, P. (2016). Challenges and opportunity of in vitro propagation of Paulownia tomentosa Steud for commercial production in Nepal. Int. J. Appl. Sci. Biotechnol., 4(2):155-160.
Lima-Brito, A.; Resende, S.V.; Lima, C.O.C.; Alvim, B.M.; Carneiro, C.E. and Santana, J.R.F. (2011). In vitro morphogenesis of Syngonanthus mucugensis Giul. subsp. mucugensis. Ciênciae Agrotecnologia, 35:501-510.

Lloyd, G., and McCown, B. (1980). Commercially feasible micropropagation of mountain laurel, Kalmia latifolia, by use of shoot tip culture. Proc. Int. Plant Prop. Soc., 30:421-427.

Lobna, S. (2008). A micropropagation protocol of Paulownia kawakamii through in vitro culture technique. Australian Journal of Basic and Applied Sciences, 2(3):594-600.

Moges, A.D.; Karam, N.S., and Shibli, R.A. (2004). Cryopreservation of African violet (Saintapulia ionantha Wendl.) shoot tips. In Vitro Cell Division Bioliology Plant, 40:389-398.

Murashige, T. and Skoog, F. (1962). A revised medium for rapid growth and bioassays with tobacco tissue cultures. Physiology Plant., 15:473-497.

Nada, B.B. and Taoufik, B. (2013). In vitro propagation of a forest tree Paulownia tomentosa (Thunb.) Steud. a valuable medicinal tree species. Albanian J. Agric. Sci., 12(1):37-42.

Ozudogru, E.A.; Previati, A. and Lambardi, M. (2010). In vitro Conservation and Cryopreservation of Ornamental Plants. In Jain, S.M. and Ochatt, S.J. (eds.). Protocols for in vitro Propagation of Ornamental Plants. Humana Press, Springer, New York, pp: 303-324.

Rabba'a, M.; Shibli, R.A. and Shatnawi, M.A. (2012). In vitro medium-term conservation of felty germander (Teucrium Polium L.) micro-shoots. Jordan Journal of Agricultural Sciences, 8(4):523-544.

Sharaf, S.A., Shibli, R.A.; Kasrawi, M.A., and Baghdadi, S.H. (2012). Cryopreservation of wild shih (Artemisia herba-alba) Asso. shoot tips by encapsulation dehydration 


\section{A.A. El-Homosany and T.M. Noor El-Deen}

and encapsulation-vitrification. Plant Cell Tissue and Organ Culture, 108:437-444.

Shibli, R., Shatnawi, M.; Ajlouni, M.; Jaradat, A., and Adham, Y. (1999). Slow growth in vitro conservation of the bitter almond (Amygdalus communis L.). Advances in Horticultural Sciences, 13:133-134.

Shibli, R.A.; Subaih, W. and Abdelrahman, N. (2005). Effect of different carbohydrates on in vitro maintenance of date palm embryogenic callus. Advances in Horticulture Science, 19:172-175.

Si, C.L.; Liu, S.C.; Hu, H.Y.; Jiang, J.Z.; Yu, G.J.; Ren, X.D. and Xu, G.H. (2013). Activity guided screening of the antioxidants from Paulownia tomentosa var. tomentosa Bark. Bioresources, 8(1):628 -637.

Smejkal, K.; Holubova, P.; Zima, A.; Muselik, J. and Dvorska, M. (2007). Antiradical activity if Paulownia tomentosa (Scrophulariaceae) Extracts. Molecules, 12(6):1210-1219.

Snedecor, C.W. and Cochran, W.G. (1982). Statistical Methods. $7^{\text {th }}$ Ed. The Iowa State University in Ames, Iowa, USA.

Tahtamouni, R.; Shibli, R.A., and Ajlouni, M. (2001). Growth responses and physiological disorders in wild pear (Pyrus syriaca Bioss.) during slow growth in vitro preservation on osmostressing media. Plant Tissue Culture, 11:15-23.
Taiz, L. and Zeiger, E. (2002). Plant Physiology, $3^{\text {rd }}$ Ed. Sinauer Associates Pubilsher, Massachusetts, USA, 690 p.

Ting, H.; Brajesh, N.V.; Zachary, D.P.; Prahlad, P. and Nirmal, J. (2016). Paulownia as a medicinal tree: Traditional uses and current advances. European Journal of Medicinal Plants, 14(1):1-15.

Tyagi, R.K.; Goswami, R.; Sanayaima, R.; Singh, R.; Tandon, R. and Agrawal, A. (2009). Micropropagation and slow growth conservation of cardamom (Elettaria cardamomum Maton). In Vitro Cell Dev. Biol. Plant, 45:721-729.

Watt, M.P.; Banasiak, M.; Reddy, D.; Albertse, E.H. and Snyman, S.J. (2009). In vitro minimal growth storage of Saccharum spp. hybrid (genotype 88H0019) at two stages of direct somatic embryogenic regeneration. Plant Cell Tissue Organ Cult., 96:263-271.

Younis, L.S. (2012). In vitro Multiplication and Conservation of Acheillea fragrantissima (Foorssk.) Sch. Bip. M.Sc. Thesis., Fac. Agric., University of Jordan, Amman, Jordan.

Zhu, Z.H.; Chao, C.J. and Lu, X.Y. (1986). Paulownia in China: Cultivation and Utilization. Asian Network for Biological Sciences \& International Development Research Centre, Beijing, 65 p.

$$
\begin{aligned}
& \text { الحفظ المعملى للبولونيا تومينتوزا }
\end{aligned}
$$

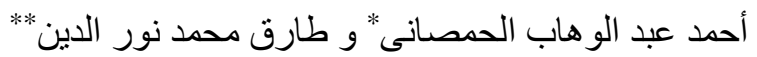

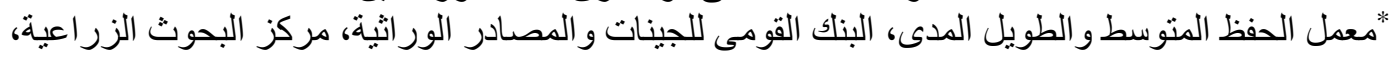

$$
\begin{aligned}
& \text { الجيزة، مصر لالجينات } \\
& \text { ** قسم بحوث الزينة وتنسيق الحدائق، معهد بحوث البساتين، مركز البحوث الزر اعبة، الجيزة، مصر }
\end{aligned}
$$




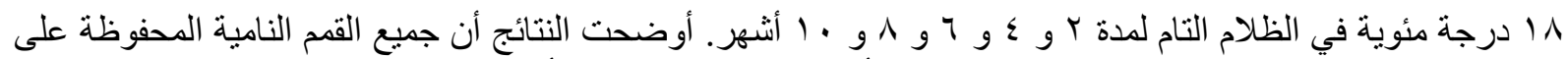

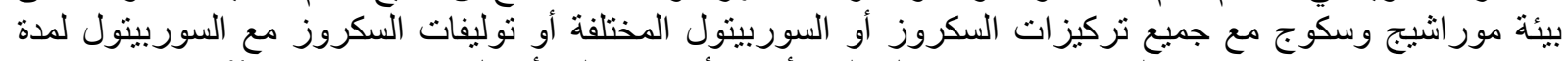

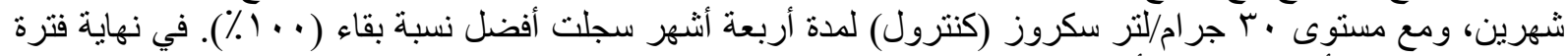

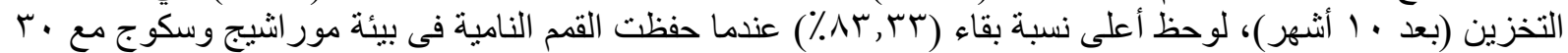

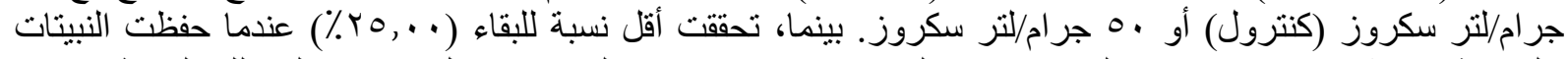

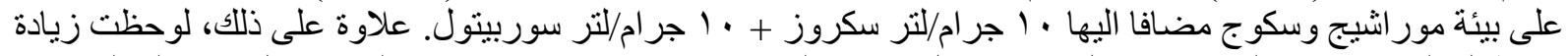

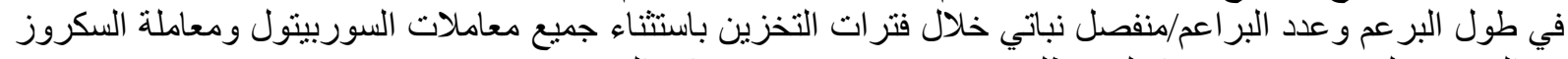

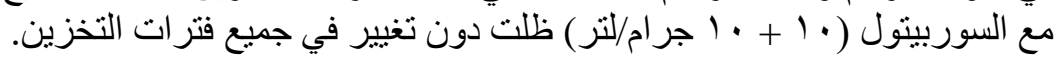

